\title{
Laurenti divo: Faunus, Pan and Silvanus in Virgil's Aeneid
}

Laurenti divo: Fauno, Pan y Silvano en Eneida de Virgilio

Lee Michael Fratantuono

Ohio Wesleyan University, Estados Unidos

lmfratan@owu.edu

\section{Resumen:}

Virgilio emplea varias deidades rurales en su Eneida como un medio para explicar cómo la relación conflictiva entre la Troya de Eneas y la Italia de Turno se reconciliarán en la futura Roma.

Palabras Clave: Virgilio, Fauno, Silvano, Pan, Italia, Troya.

\section{Abstract:}

Virgil employs various rural deities in his Aeneid as a means to explicate how the conflicted relationship between Aeneas' Troy and Turnus' Italy will be reconciled in the future Rome.

KEYWORDs: Virgil, Faunus, Silvanus, Pan, Italy, Troy.

The rural deity Faunus is referenced several times in the second half of Virgil's epic Aeneid. ${ }^{1}$ Introduced in the opening book of what has been called Virgil's Iliad (Gransden, 1984), the god figures in a significant scene of the twelfth and last movement of the poem. Between these framing appearances in Aeneid 7 and 12, there is one additional reference to the god in Book 10. We shall endeavor to examine closely the role of Faunus in Virgil's work (with particular consideration of his connection to the Arcadian god Pan), together with that of the forest deity Silvanus. Detailed consideration of the appearances of these rustic spirits in Virgil's epic will serve to illustrate how the poet employs these gods of nature in his consideration of the relationship between Aeneas' Troy and Turnus' Italy.

Faunus is introduced early in Virgil's description of the state of affairs in Latium on Aeneas' arrival. King Latinus was the son of Faunus and the Laurentine nymph Marica:

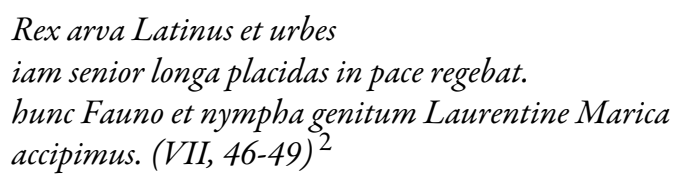

Latinus was born of the rural god and a local nymph; Faunus, Virgil proceeds to note, was the son of Picus, himself the son of the great god Saturn (VII, 48-49 ... Fauno Picus pater, isque parentem / te, Saturne, refert, tu sanguinus ultimus auctor). ${ }^{3}$ The genealogy comes to something of a close with Latinus, in that we learn at once that his own son died prematurely (VII, 50-51, filius huic fato divum prolesque virilis / nulla fuit, primaque oriens erepta iuventa est). No son, then, but a daughter: Latinus had Lavinia, and she was sought in marriage by a wide range of suitors, most prominent among them the prince Turnus (VII, $52 \mathrm{ff}$.). Latinus' lack of a son points to a critical moment in the genealogy of the Latins; the race is poised to continue in a direction to be determined in part by who will marry Lavinia.

Latinus' origins present significant mythological problems. ${ }^{4}$ His mother Marica is mentioned only here in Virgil. Certainly there was a tradition that Circe was the mother of Latinus, a result of her union with Odysseus. ${ }^{5}$ This Circean origin is alluded to at XII, 154, Solis avi specimen, where Latinus makes reference 
to his solar pedigree - Circe was the daughter of Helios. On arrival at the coast of Italy Aeneas and his Trojans skirted the shores of Circe's realm (VII, 10, proxima Circaeae raduntur litora terrae). Indeed Circe is prominently featured in the opening of the second half of Virgil's epic; already in Buthrotum Aeneas and his men had been warned that they would pass by her realm en route to Italy. ${ }^{6}$ At VII, 189-191, we learn that Circe was the bride of Picus, and that the sorceress spouse was the cause of his transformation into a woodpecker.

Various attempts have been made since antiquity to account for the apparent inconsistency in Latinus' maternal history; already in the Servian tradition the problem had been recognized. ${ }^{7}$ Servius knew of a solution by which Marica was simply conflated with Circe; Marica also had associations with both Venus and Diana. Saint Augustine was aware of the confusion as to the identity of the nymph, where he refers to Marica, "whoever she may be." 8 The problems of Latinus' genealogy, as well as of the Saturnian age in Italy, are not of particular concern for an explication of Faunus' role in the epic. Virgil's association of Latinus with Faunus invests the Latin king with indigenous, rural credentials that present the Latins as the age-old possessors of the fields of central Italy.

Latinus' daughter Lavinia was the object of dramatic portents (both apian and fiery); ${ }^{9}$ in response to the clear enough omens the king consulted his divine father, whose oracular powers are taken for granted in Virgil's narrative:

At rex sollicitus monstris oracula Fauni,
fatidici genitoris, adit lucosque sub alta
consulit Albunea, nemorum quae maxima sacro
fonte sonat saevamque exhalat opaca mephitim. (VII, 81-84)

The connection of Faunus with prophecy is principally etymological; the very name of the name implies the power to make pronouncements (Faunus/ fari; cf. fatidici). ${ }^{10}$

Virgil describes Faunus' oracle in some detail. ${ }^{11}$ It was a pan-Italian and Oenotrian place of consultation; there was a priestess who slept on the fleeces of slaughtered sheep as she sought to receive messages from the gods while in repose (VII, 85-88). ${ }^{12}$ Latinus himself slaughtered a hundred sheep and engaged in the same sort of incubation ritual to consult his immortal father. ${ }^{13}$ The king was not disappointed; Faunus offered a response that constitutes his only speech in the epic:

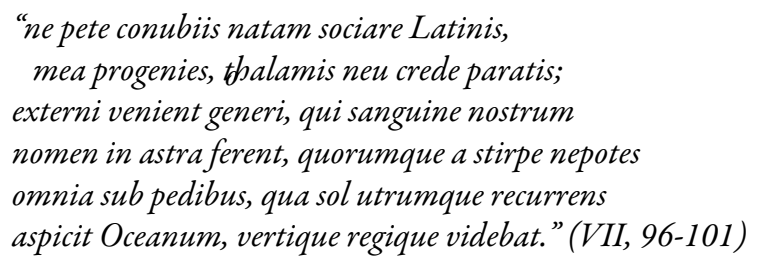

In terms of the narrative of the Aeneid the crucial information revealed in the god's warning is about the need to seek a foreign husband for Lavinia, and not to entrust the princess to a Latin suitor. The admonition thalamis neu crede paratis would seem to be aimed at Turnus in particular, regardless of whether one might want to quibble as to his Rutulian versus Latin origins. ${ }^{14}$ But fully two-thirds of Faunus' prophecy is concerned not with the nuptials of Lavinia per se, but with the forthcoming domination of Rome over the known world. It will be the name of the Latins that will carried to the stars - nostrum nomen in astra ferant. "Nostrum nomen" refers to Faunus himself and to his progeny. This act of exalting the name of the Latins will come about by blood (sanguine) - a clear enough reference to the forthcoming war in Italy. ${ }^{15}$ "Blood" in the immediate context implies both the eventual union of Trojans and Latins, and also the grim conflict that will be waged before any such coupling. 
Faunus' speech is of a piece with the sentiments of Jupiter's assurances to his daughter Venus about the future of the Trojans at I, $257 \mathrm{ff}$.; the supreme god also referenced the ocean (I, 287) and the generally limitless character of the empire destined to come into being. Jupiter also predicted a terrible war in Italy (I, 263-264), in a passage that we shall return to in due course.

The revelations of Faunus were given in the silent dead of night; Latinus, however, did not conceal the words of his divine sire, and Rumor soon enough spread the report (VII, 102-105). ${ }^{16}$ The connection of the oracle to the contemporaneous arrival of Aeneas' Trojans offered an obvious enough fulfillment of Faunus' advice. ${ }^{17}$

In the narrative of Aeneid VII, then, Faunus' principal role is in the attempted settlement of the crucial question of who will marry Lavinia. He is a progenitor of Latinus, of close genealogical connection to the royal family into which Aeneas will marry. ${ }^{18} \mathrm{He}$ is a native Italian spirit par excellence, a local god associated with the world of nature and the rural haunts of central Italy. By the time we come near to the end of the epic, in the long narrative of the climactic single combat of Aeneas and Turnus, he will be unquestionably associated with aiding the very hero whose claim to Lavinia is seemingly called into question by the oracle from Book VII.

Faunus is not referenced again in the epic until, one might argue, VIII, 314, where we find the Arcadian Evander in the midst of his tour with Aeneas of what the audience knows will be the future site of Rome. Here, another aged monarch is introduced in association with Faunus; Evander notes that of old, fauns and nymphs inhabited the groves through which the Trojan hero is being escorted:

haec nemora indigenae Fauni Nymphaeque tenebant (VIII, 314)

Only here in the epic do we find a reference to plural "fauns". ${ }^{19}$ The emphasis is on the indigenous nature of these woodland spirits; like the local nymphs the fauns were always here, native inhabitants of central Italy. Indeed they even preceded the arrival of Saturn. ${ }^{20}$ This would seem to pose something of an inconsistency in light of VII, 46 ff., where Saturn was the father of Faunus and the grandfather of Latinus; it may be relevant that in the one passage the poet-narrator is our source, while here Evander is describing the local history. ${ }^{21}$ Fauns and nymphs were a part of the landscape of Latium from time immemorial. Significantly, the adjective indigenus occurs only twice in Virgil: here to describe the fauns, and at XII, 823 in a key passage about the Latins and the future Rome that we shall consider below.

Latinus is not the only son of Faunus to be named in the Aeneid. At X, $551 \mathrm{ff}$. Aeneas encounters the hero Tarquitus as yet another victim in the midst of his bloody vengeance for the death of Pallas: ${ }^{22}$

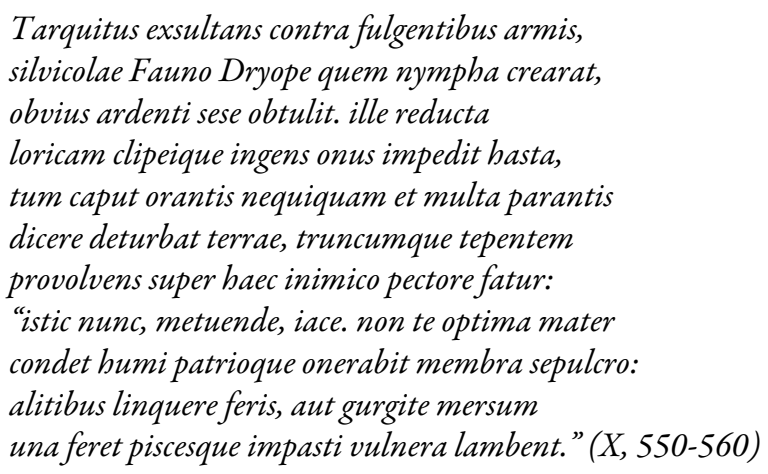

The passage offers an extraordinary commentary on many of the relevant problems associated with the depiction of Faunus in the epic. The oraculae associations of the god are referenced in the juxtaposition of X, 554, fatur, and 555, tace: Aeneas will now speak, and the son of the god will be silent. ${ }^{23}$ Tarquitus will be denied burial, and the refusal is conveyed in language that specifically references both the noble Dryope (557, 
optima mater) and Faunus himself ( 558 patrio ... sepulcro). Aeneas insults the divine origins of this Etruscan ally of Turnus; he will be left as prey either to birds or hungry fish -the enraged Trojan envisages the worst of fates both on land and in the sea. Aeneas' anger is intensely personal in the wake of the death of his young friend (556, inimico pectore). ${ }^{24}$

Tarquitus is a half-brother of Latinus, another son of Faunus and a nymph. Dryope appears only here in Virgil; the connection of her name to oak trees recalls Aeneid VIII, 315, gensque virum truncis et duro robore nata, with reference to the primeval age when fauns and nymphs inhabited the fields of Italy. Aeneas is depicted here explicitly as the slayer of the son of a native god of Latium; Tarquitus' attempt at supplication (554, orantis) will be rejected by the brutal act of beheading, a method of killing that responds all too vividly to the attempt of Faunus' son to speak. ${ }^{25}$

Dryope may figure only here in Virgil, but at IV, 146 the Dryopes are mentioned as part of the retinue of the god Apollo in the simile that compares Aeneas at Dido's hunt to the god. "A rude and predatory Greek tribe", ${ }^{26}$ their ancestor Dryops was a son of Apollo and Dia, the daughter of Lykaon ${ }^{27}$ (cf. Virgil's Homeric model for Tarquitus' death scene). A Trojan by the name of Dryops is slain at X, $345 \mathrm{ff}$.; his death scene emphasizes his loss of voice as a spear pierces his throat. ${ }^{28}$ These nominal connections do not add much to our appreciation of the scene of Aeneas' slaying of Tarquitus; the significant detail in "Dryope" is her connection to oak trees, with its reminiscence of Evander's remarks about the primeval inhabitants of central Italy.

The Tarquitus passage connects Aeneas to Faunus lore, and not to his credit. ${ }^{29}$ The Trojan leader is portrayed in a moment of violent rage, his victim the son of a native Italian god. The references to Faunus in Aeneid VII and X prepare the audience for the crucial, climactic passage in Book XII where Turnus invokes the woodland god for aid in his combat with Aeneas. ${ }^{30}$ The locus of the invocation is a wild olive of Faunus:

Forte sacer Fauno foliis oleaster amaris
hic steterat, nautis olim venerabile lignum,
servati ex undis ubi figere dona solebant
Laurenti divo et votas suspendere vestes;
sed stirpem Teucri nullo discrimine sacrum
sustulerant, puro ut possent concurrere campo. (XII, 766-771)

The oleaster of Faunus had been cut down indiscriminately (nullo discrimine) by Aeneas' Teucrians in order to facilitate the use of the plain for military operations. ${ }^{31}$ There is a clear ethnic juxtaposition in Virgil's description of the scene between the Teucri who violate the sanctity of the tree, and the Laurentian god whose oleaster has been desecrated. ${ }^{32}$ The tree had been a locus for shipwreck survivors to offer garments in votive thanks to the god who had saved them from drowning. ${ }^{33}$ Servati ex undis recalls III, 209, servatum ex undis, of Aeneas on his arrival at the Strophades (the realm of the Harpies). But the connection of Faunus' olive to shipwrecks has not been satisfactorily explicated; the commentators tend to be content with generic observations about the kindly favor of the god (there is likely an allusion to Favonius, the west wind, with his similar name). In the context of the Aeneid, the preeminent image of rescue from storms at sea is that of Aeneas and his men from the Junonian tempest of Book I. The Trojans have now reached their long awaited new home; the very ships of Aeneas have been transformed into sea nymphs and the perils of the sea have been relegated to memory. ${ }^{34}$

All that now remains of Faunus' tree is the stump of its trunk. ${ }^{35}$ Aeneas' spear now stands fast in the tough root. We might well have forgotten how the heroes had clashed with the hurling of spears (XII, $711 \mathrm{ff}$.); now we learn that Aeneas' weapon has missed its mark and is stuck fast in the wild olive trunk. ${ }^{36}$ Turnus at once invokes the Laurentine god, imploring him to retain the spear and to deny its use to the Trojan hero: 
Terra tene, colui vestros si semper honores,

quos contra Aeneadae bello fecere profanos." (XII, 777-779)

The prayer is elegant in its simplicity and balance of economical expression: Turnus has never neglected the worship of Faunus, and Terra, whereas the sons of Aeneas have profaned and desecrated nature's sacred locale. Turnus' petition is granted; Aeneas is unable to retrieve his weapon, despite his tremendous efforts (XII, 780-783). Faunus, Terra, and the very remains of the god's tree all underscore the quality of indigenous inhabitation, in contrast to Trojan invasion and profanation.

While Aeneas tries in vain to dislodge his spear, Turnus' divine sister Juturna utilizes the critical moment of reprieve to return her brother's sword. Reemploying the disguise of his charioteer, the nymph restores the weapon; in the act of return she is described as the "Daunian goddess": procurrit fratrique ensem dea Daunia reddit (XII, 785). "Daunus" provides a neat verbal echo of "Faunus"; once again nymphs are associated with fauns, as here Juturna joins Faunus in assisting the Italian warrior. ${ }^{37}$

Venus is enraged by the action of the "audacious nymph", and she proceeds at once to fetch Aeneas' spear for him: quod Venus audaci nympha indignata licere / accessit telumque ab alta radice revellit (XII, 786-787). Earlier in the book Venus had intervened to assist in the healing of Aeneas' serious arrow wound (XII, 411 ff.), and now she reacts with indignation and immediate aid to her son in the wake of Juturna's (and Faunus', implicitly) assistance to Turnus. ${ }^{38}$ Both warriors now have their weapons, and both now reengage in the fight, eager and renewed in strength by virtue of the signal signs of divine favor they have enjoyed.

Crucially, the narrative now changes to another divine plane, this time with the supreme god Jupiter and his sororial consort Juno (XII, $791 \mathrm{ff}$.). In the immediate aftermath of the interventions of Faunus et al., Jupiter and Juno engage in the immortal colloquy that provides something of a twist so near the end of Virgil's epic.

On the matter of Turnus' salvation, and indeed of Aeneas' future godhood, Juno confesses that she will yield to the dictates of fate. But there is one matter, she notes, that is not held fast by such immutable bonds -and therein she will find the seeds of her own victory after all:

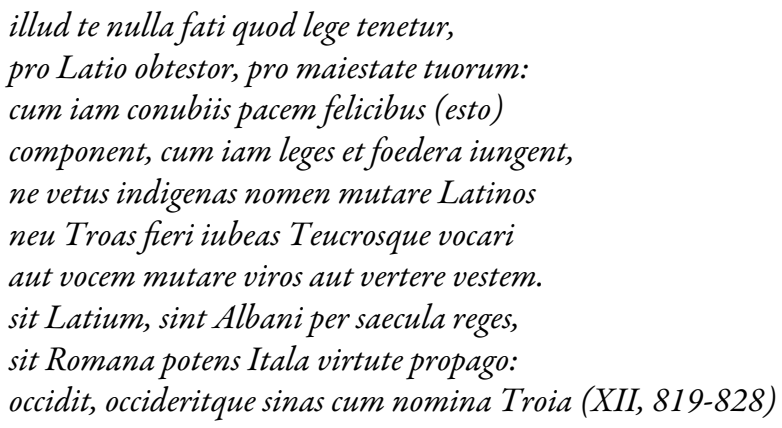

Herein is found the obituary for Troy; hereby does Juno secure the death sentence for Priam's eastern kingdom. ${ }^{39}$ There was nothing of this news when Jupiter had a similar conversation with his daughter Venus in Book I; the two speeches of Jupiter to important women in his divine family serve to frame the action of the poem. Neither Venus nor Aeneas is ever made privy to the decision that Troy will be dead for good and all (indeed Turnus and his allies remain ignorant of this key revelation as well).

For Jupiter agrees and once and without equivocation to Juno's request:

sermonem Ausonii patrium moresque tenebunt, utque est nomen erit; commixti corpore tantum subsident Teucri. morem ritusque sacrorum adiciam faciamque omnes uno ore Latinos. binc genus Ausonio mixtum quod sanguine surget, 
supra homines, supra ire deos pietate videbis,

nec gens ulla tuos aeque celebrabit honores (XII, 834-840)

There is even a subtle hint here aimed at Aeneas; the future genus (i.e., the Roman race) will surpass both men and gods in the exercise of pietas -Aeneas will, after all, no longer be the consummate practitioner of that virtue. ${ }^{40}$ Aeneas' Teucrians will be mingled with the Ausonians in body but not in mind, we might say: the Ausonians will retain their language and customs, and the future Latins will be like the Latins of old not like the Trojans who have so recently landed in Latium.

The spear of Aeneas hereby becomes a symbol of the grafting of the Trojans onto the Italian. Aeneas' spear was like some shoot that had been inserted into the native tree; its removal is emblematic of the force of Jupiter's announcement about the sinking down or suppression of Troy (Teucri subsident). ${ }^{41}$ On the one hand, there is no question that Trojans and Ausonians will be commingled. On the other, there is also no doubt as to which of the two entities will be preserved in terms of sermo and mores. The future Romans will speak with one language, and it will be Latin (XII, 837). It will be the Trojans who receive customs and language; once the union is accomplished no one, we might say, will be speaking Trojan. The capricious Venus is left unaware of settlement of Jupiter and Juno; her last appearance in the epic is in the act of removing the spear of Aeneas from Faunus' tree -a symbolic act of far greater significance than the goddess might appreciate.

We can thus trace a clear progression in the Virgilian references to Faunus. Introduced in the first book of the second half of the epic, the woodland god is directly associated both with Latinus' lineage and the question of the marriage of Lavinia. Faunus' connection to the site of the future Rome is underscored in Book VIII by Evander's reference to the indigenous fauns and nymphs of the locale - no personages could claim a longer ancestry in the environs of Rome than the indigenous fauns and nymphs. The Trojan Aeneas is portrayed in direct conflict with both Faunus' son the Etruscan Tarquitus, and the Rutulian Turnus who successfully invokes the god for help against his foe. In the immediate aftermath of the episode of Faunus' tree and Aeneas' spear, Juno successfully secures Jupiter's agreement about what we might call the victory of the indigenae Latins - the future Rome will be Latin and not Trojan, true to its indigenous, we might say faunian roots.

Satyrs, nymphs, and fauns were mentioned by Virgil's poetic predecessor Lucretius as part of his commentary on the phenomenon of the echo. ${ }^{42}$ For Lucretius, the belief in such woodland deities is connected both to ignorance of the science of echoes, and to the human need to feel that one is not entirely alone -the forests and meadows, in other words, are indeed inhabited by someone. Alongside the nymphs and fauns, Lucretius also envisages the image of the goat god Pan, a preeminent god of music with his sylvan or forest muse. ${ }^{43}$

The Arcadian god Pan is mentioned but once in Virgil's Aeneid, and only in passing -though in a passage of great import. ${ }^{44}$ Aeneas' tour guide -the Arcadian Evander- points out the Lupercal, which was named, the aged king notes, in the Parrhasian fashion after Lycaean Pan:

... et gelida monstrat sub rupe Lupercal

Parrhasio dictum Panos de more Lycaei. (VIII, 343-344)

The Lupercal -a cave on the Palatine hill- was the traditional locus for the suckling of the infants Romulus and Remus by the she-wolf. ${ }^{45}$ The Lupercalia was celebrated in Rome on 15 February; the Faunalia in honor of the god Faunus on the thirteenth. Virgil's two verses on the Lupercal and Pan display vertical etymological play: Lupercal (343) and Lycaei (344) evoke respectively the Latin and Greek words for wolf. ${ }^{46}$ Pan was a defender of flocks against lupine predation; ${ }^{47}$ in Virgil's sole mention of the god, he is associated closely with wolves and the very place where Rome's eponymous founder was reared. In Evander's reference to the 
Lupercal, the god Pan is prominently featured at the center of verse 344; the same line is artfully balanced with evocative references to Arcadia and Arcadian lore. ${ }^{48}$

Pan and Faunus were closely conflated in the Roman religious imagination. ${ }^{49}$ Evander brings the worship of Pan from Arcadia to Rome; the Arcadian Lykaia becomes the Roman Lupercalia. The assimilation of Pan and Faunus is especially prominent in the proem to the first georgic, where the appellation favens is applied to Pan -an etymological nod to Faunus. ${ }^{50}$ In the etiological context of Aeneid VIII, Evander is presented as having introduced the worship of the Arcadian Pan to Latium, where the rustic god was associated easily enough with Faunus. ${ }^{51}$

In the Aeneid Pan is mentioned but once, and -in the same book as his fellow rustic divinity- so too Silvanus. Silvanus was a deity responsible for the forests (silva) denoted by his very name; he has obvious affinities with the fauns and nymphs, indeed also with Pan. ${ }^{52}$ What is significant about the solitary mention of Silvanus in Aeneid VIII is that it balances the similar mention of Pan. A woodland god is depicted in close association with a major element of Virgil's depiction of the future Rome. With Pan there was the connection to the Lupercal with its cave of the she-wolf. Silvanus is cited as the patron of the grove at Caere where Aeneas receives the divinely crafted shield that displays in stunning art the future history of Rome from the she-wolf through the victory over Antony and Cleopatra at Actium. ${ }^{53}$

Like Faunus, Silvanus was a god of impeccable Italian origins, indeed another reflection of the "Italian animism ... rooted in the conception of spirits ... inhabiting special places" ${ }^{54}$ The fact that Virgil notes that the ascription of the grove and a festal day to Silvanus was an institution of the Pelasgians serves again to underscore the prehistoric origins of the cult:

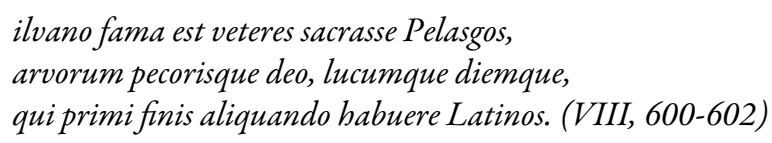

Once again we see an emphasis on priority: the Pelasgians were the first (primi) to inhabit the territory of the Latins. ${ }^{55}$ There are verbal echoes between the Caere/ Silvanus locus and that of Lupercal/ Pan: we may compare the gelida rupes of VIII, 343 and the gelidus lucus of $597 .{ }^{56}$ It is eminently appropriate that Silvanus' grove would be the site for the bestowal of a shield that displays res Italas and Romanorum triumphos (VIII, 626). Virgil's gesture is subtle - all that matters is that Silvanus be the god in whose grove the shield is presented.

Like the fauns and Pan, Silvanus is also named in the proem to the first georgic. ${ }^{57}$ Pan, the aged Silvanus, and the sorority of nymphs are known to that fortunate man who is familiar with the rustic world. ${ }^{58}$ Together with Pan, Silvanus is among those denizens of forest and glade who come to the comfort of Gallus. 59 But in the sole appearance of the forest god in Virgil's epic, as with Pan he is mentioned in connection with the ultimate triumph of Rome. Book VIII is a quiet interlude in the midst of the war in Italy; it is an Arcadian, idyllic book in which both Pan and Silvanus find a place -though in association with the coming historical and political reality.

The ultimate problem of the second half of Virgil's Aeneid is the question of the union of Trojans and Italians. Latinus' grandmother Circe had attempted a similar sort of blending in the matter of the horses of her divine father the sun. Helios had immortal horses (as befitting his lordly status and the needs of his solar chariot). Circe stole divine horses from the sun and mated them with a mortal mare. The resulting stock of horses descended from this theft and subsequent breeding were in the possession of Latinus, who made a wedding present of them to Aeneas: 
semine ab aetherio spirantis naribus ignem,

illorum de gente patri quos daedala Circe

supposita de matre nothos furata creavit. (VII, 280-283)

Bastard horses bred from a sorceress's act of theft: a baleful nuptial gift, one might think -but one certainly invested with a sort of equine commentary on the state of affairs in Latium in the wake of the Trojan landing. ${ }^{60}$ There are two yoked horses, and they are emblematic of war. ${ }^{61}$ The offspring that result from Circe's breeding experiment are bastards -the pure, immortal bloodline is no more. ${ }^{62}$ The question remains of which of the two stocks will prove to be superior in terms of the marriage of Aeneas and Lavinia. Apart from any questions about Aeneas' destined divine status, certainly in terms of the revelations of Jupiter to Juno in Aeneid XII, it will be Lavinia's Italians and not Aeneas' Trojans who will enjoy status.

Faunus and the nymph Juturna figure in the epic's final scene on the mortal plane before Virgil proceeds to the divine conversation of Jupiter and Juno in which the sermo and mores of the future Rome are settled. The fauns and nymphs of central Latium were the original denizens of grove and glade; they predate even any Saturnian arrival in Italy. The ultimate victory in Virgil's Italian war would belong to the indigenae, who on the divine level include the fauns and the nymphs, and on the mortal the Latins. ${ }^{63}$ Thus the fauns and nymphs do their part in supporting the efforts of the Rutulian Turnus against Aeneas in the climactic single combat of Aeneid XII. Turnus may not have been a Latin by blood, but he was the champion of the Latin cause against the Trojan invaders. The Italians and the Trojans were destined to become one people, but in her act of removing the engrafted spear of Aeneas from Faunus' tree, the goddess Venus unwittingly signaled the future inferiority of Troy in the ethnic equation of the future Rome.

\section{References}

Armstrong, R. (2019). Vergil's Green Thoughts: Plants, Humans, \& the Divine. Oxford: Oxford University Press.

Baccini Leotardi, P. (1985). Fauno. In F. Della Corte (Ed.), Enciclopedia virgiliana II (pp. 480-481). Roma: Istituto della enciclopedia italiana.

Bailey, C. (1935). Religion in Virgil. Oxford: Oxford University Press.

Balk, C. (1968). Die Gestalt des Latinus in Vergils Aeneis. Leipzig: Heidelberg.

Binder, G. (2019). P. Vergilius Maro Aeneis: Ein Kommentar, Band 3 Kommentar zu Aeneis 7-12. Trier: Wissenschaftlicher Verlag.

Boas, H. (1938). Aeneas' Arrival in Latium: Observations on Legends, History, Religion, Topography and Related Subjects in Vergil, Aeneid VII, 1-135. Amsterdam: N.V. Noord-Hollandsche Uitgeversmaatschappij.

Cairns, F. (1989). Virgil's Augustan Epic. Cambridge: Cambridge University Press.

Conte, G. B. (2019). Publius Vergilius Maro Aeneis. Berlin-New York: Walter de Gruyter (editio altera).

de Melo, W. D. C. (2019). Varro: De Lingua Latina. Oxford: Oxford University Press.

Della Corte, F. (Ed.). (1988). Enciclopedia virgiliana III. Roma: Istituto della enciclopedia italiana.

Dorcey, P. F. (1992). The Cult of Silvanus: A Study in Roman Folk Religion. Leiden-New York-Köln: E. J. Brill.

Dyson, J. T. (2001). King of the Wood: The Sacrificial Victor in Virgil's Aeneid. Norman: The University of Oklahoma Press.

Eden, P. T. (1975). A Commentary on Virgil, Aeneid VIII. London: E. J. Brill.

Fordyce, C. J. (1977). Publi Vergili Maronis Aeneidos Libri VII-VIII. Oxford: Oxford University Press.

Fratantuono, L. M. (2019). Alma Phoebe: Lunar References in Virgil’s Aeneid. Graeco-Latina Brunensia, 24(1), 61-79.

Fratantuono, L. M. and Smith, R. A. (2018). Virgil, Aeneid 8: Text, Translation, and Commentary. Leiden-Boston: Brill.

Gransden, K. W. (1984). Virgil's Iliad: A Study in Epic Narrative. Cambridge: Cambridge University Press. 
Grassmann-Fischer, B. (1966). Die Prodigien in Vergils Aeneis. München: Wilhelm Fink Verlag. Hardie, P. (1986). Virgil's Aeneid: Cosmos and Imperium. Oxford: Oxford University Press. Harrison, S. J. (1991). Vergil: Aeneid 10. Oxford: Oxford University Press.

Hejduk, J. D. (2014). Faunus. In R. F. Thomas and J. T. Ziolkowski (Ed.), The Virgil Encyclopedia, Volume II (p. 476). Malden, Massachusetts: Wiley-Blackwell.

Horsfall, N. (2000). Virgil, Aeneid 7, A Commentary. Leiden-Boston-Köln: Brill.

Jeunet-Mancy, E. (2012). Servius: Commentaire sur l'Enéide de Virgile, Livre VI. Paris: Les Belles Lettres.

Katz, R. (2014). Beheading. In R. F. Thomas and J. T. Ziolkowski (Ed.). The Virgil Encyclopedia, Volume I (pp. 177-178). Malden, Massachusetts: Wiley-Blackwell.

Mackie, C. J. (1988). The Characterisation of Aeneas. Edinburgh: Scottish Academic Press.

McKay, A. G. (1970). Vergil's Italy. Greenwich, Connecticut: New York Graphic Society Ltd.

Montenegro Duque, A. (1949). La onomástica de Virgilio y la antigüedad preitálica. Salamanca: Consejo Superior de Investigaciones Científicas.

Nisbet, R. G. M. and N. Rudd (2004). A Commentary on Horace, Odes, Book III. Oxford: Oxford University Press.

Nurtantio, Y. (2013). Le silence dans l'Enéide. Bruxelles: EME.

O'Hara, J. J. (1990). Death and the Optimistic Prophecy. Princeton: Princeton University Press.

O'Hara, J. J. (2017). True Names: Vergil and the Alexandrian Tradition of Etymological Wordplay. Ann Arbor: The University of Michigan Press.

Ottaviano, S. and Conte, G. B. (Ed.). (2013). P. Vergilius Maro Bucolica, Georgica. Berlin-New York: Walter de Gruyter.

Paschalis, M. (1997).Virgil's Aeneid: Semantic Relations and Proper Names. Oxford: Oxford University Press.

Pease, A. S. (1935). Publi Vergili Maronis Aeneidos Liber Quartus. Cambridge, Massachusetts: Harvard University Press.

Putnam, M. C. J. (1970). Aeneid VII and the Aeneid. The American Journal of Philology, 91(4), 408-430.

Richter, W. (1957). Vergil: Georgica. München: Max Hueber Verlag.

Rivoltella, M. (2005). Le forme del morire: La gestualità nelle scene di morte dell' «Eneide». Milano: Vita e Pensiero.

Robinson, M. (2011). A Commentary on Ovid's Fasti, Book 2. Oxford: Oxford University Press.

Schauer, M. (2007). Aeneas dux in Vergils Aeneis: Eine literarische Fiktion in augusteicher Zeit. München: Verlag C.H. Beck.

Smith, R. A. (2005). The Primacy of Vision in Virgil's Aeneid. Austin: The University of Texas Press.

Stahl, H. P. (2015). Poetry Underpinning Power: Vergil's Aeneid: The Epic for Emperor Augustus, A Recovery Study. Swansea: The Classical Press of Wales.

Steiner, H. R. (1952). Der Traum in der Aeneis. Bern: Verlag Paul Haupt.

Tarrant, R. (2012). Virgil: Aeneid Book XII. Cambridge: Cambridge University Press.

Thomas, R. F. (1988). Tree Violation and Ambivalence in Virgil. Transactions of the American Philological Association, 118, 261-273.

Tilly, B. (1947).Vergil's Latium. Oxford: Basil Blackwell.

Tilly, B. (1969). P. Vergili Maronis Aeneidos Liber XII with Vocabulary. London: University Tutorial Press Ltd.

Traina, A. (2017, reprint of the 2004 second edition). Virgilio: l'utopia e la storia: Il libro XII dell'Eneide e antologia dell'opere. Bologna: Pátron Editore.

West, M. L. (1966). Hesiod: Theogony. Oxford: Clarendon Press.

Wimmel, W. (1973). 'Hirtenkrieg' und arkadisches Rom: Reduktionsmedien in Vergils Aeneis. München: Wilhelm Fink Verlag. 


\section{Notas}

1 On this god note especially Baccini Leotardi, (1985, pp. 480-481); Hejduk (2014, p. 476); also Bailey (1935, pp. 144-147); Dorcey (1992, pp. 33 ff.); Robinson (2011, pp. 180-181).

2 All passages from the Aeneid are cited from Conte, 2019 (editio altera).

3 For Latinus' divine family origins see further Balk (1968, pp. 8-19). For Dionysius of Halicarnassus (I, 31.2) Faunus was a king on the site of the future Rome in the days before Evander's arrival.

4 Horsfall (2000, pp. 76-79) provides a helpful start to unraveling some of the difficulties. Aeneas' trusty ambassador Ilioneus knows that Latinus is the son of Faunus in his honorific salutation of the monarch at VII, 213, rex, genus egregium Fauni. Horsfall ad loc. considers the very good question of how exactly Ilioneus knew this piece of information - evidently the Trojan reconnaissance had done an exemplary job of investigation of the relevant mythological family trees. The mention of Faunus serves in part as a reminder of the god's oracle referenced at VII, $81 \mathrm{ff}$. and its relevance to Aeneas as potential son-in-law of the Latin king.

5 Cf. Ps.-Hesiod, Theogony 1011 with M.L. West (1966, p. 434).

6 Aeneid III, 381-387. Circe is referenced near the start of Book VII, and also near the end in neat balance: cf. VII, 799, where the men who follow in Turnus wake in the catalogue of Italian heroes come from near Circe's promontory in Latium.

7 In Hyginus (Fabulae 125.20; 127.3) Latinus is the son of Circe and Telemachus; the mythographer's only apparent interest in the king is that he gave his name to the Latin language.

8 Cf. De civitate Dei II, 23 ... nec Maricae nescio cui tribuo Marii sanguineam felicitatem.

9 For the Lavinia omens note Grassmann-Fischer (1966, pp. 64-77).

10 See further here O'Hara (2017, pp. 187-188); also Paschalis (1997, p. 248).

11 There is exhaustive analysis of the ritual rubrics and the setting of the oracle at Boas (1938, pp. $178 \mathrm{ff}$.).

12 Faunus' oracle has received significant critical attention both in terms of locale and mechanism. On the site of the god's revelation note Tilly (1947, pp. 103-111).

13 For the dream-like aspects of the ritual note Steiner (1952, pp. 59-62).

14 Cf. the argument raised by Latinus' wife Amata at VII, $368 \mathrm{ff}$. where the queen notes that if Latinus has scruples on account of the oracle of the god (Faunique premunt te iussa parentis), Turnus' descent can be traced to the kings of Argos through Acrisius' daughter Danaë, who had arrived in Italy and founded Ardea. Turnus is not, strictly speaking, excluded from consideration by virtue of the language of Faunus' oracle; both Aeneas and Turnus fit the strict parameters of the god's revelation. See further Schauer (2007, p. 98).

15 Sanguine is a little word with great import; for the connection to the bloodline of the generi that will mingle with Latinus' own see the commentary notes ad loc. of Horsfall as well as of Fordyce (1977); Horsfall references O’Hara (1990, p. 63) ("clearly right to see a small ugly oracular hint of 'bloodshed' and we should not have had to wait until 1990 for this to be spelled out!").

16 For the significance of the silent night, especially in connection to the vocal god Faunus and the report of Rumor, note Nurtantio (2013, pp. 74 ff.).

17 Cf. VII, 254 et veteris Fauni volvit sub pectore sortem, where Latinus ponders the oracle during his audience with Ilioneus.

18 See further here Cairns (1989, pp. 63-64).

19 For how we proceed from the generic to the specific in the lore about fauns versus Faunus, father of Latinus see Bailey, op. cit., pp. $35 \mathrm{ff}$. "Fauns" are featured prominently in the proem to the first georgic: et vos, agrestum praesentia numina, Fauni, / ferte simul Fauniquepedem Dryadesquepuellae (I, 10-11); cf. Eclogue VI, 27-28, tum vero in numerum Faunosque ferasque videres / ludere...

20 Cf. VII, $319 \mathrm{ff}$.

21 See further here Fratantuono and Smith (2018, pp. 421-422).

22 For the allusion in the hero's name to the Tarquins, see Harrison (1991, p. 211); note also Montenegro Duque (1949, pp. 73-74). Exsultans as a descriptor recalls the name Tarquinius Superbus.

23 Tarquitus had been preparing to speak at length (X, 554-555 ... multa parantis / dicere) when he was decapitated; one almost wonders if iace at 557 should be emended to tace.

24 On how Virgil manipulates his Homeric models in this passage to heighten the ghastly effects, see Mackie (1988, pp. 168-169). Virgil's Tarquitus scenes owes much to the Homeric depiction of Achilles' slaughter of the suppliant Lykaon at Iliad XXI, 122-125.

25 Cf. here Katz, "Beheading," in Thomas and Ziolkowski (2014, pp. 177-178), with particular reference to how disturbing the whole scene is in light of Aeneas' singular quality of pietas. On instances of Virgilian decapitation note also Rivoltella (2005, p. 51 n.19). For the problem of Virgil's pietas or lack thereof in this scene note Smith (2005, p. 157).

26 So Pease (1935, p. 193). 
27 Cf. Tzetzes on Lycophron, Alexandra 480.

$28 \mathrm{X}, 347-349$... pariterque loquentis / vocem animamque rapit traiecto gutture; at ille / fronte ferit terram et crissum vomit ore cruorem.

29 For a different view that interprets Aeneas' actions here and in related passages as eminently justified in response to taunts offered to the Trojan, note Stahl (2015, pp. $134 \mathrm{ff}$.). Stahl does not address the Faunus oleaster passage from Aeneid XII in his remarks on the god.

30 For the possible connection of Faunus to the port of Ardea, Castrum Inui via the conflation of Inuus with Faunus and Pan, note Servius on Aeneid VI, 775 (with Jeunet-Mancy, 2012, ad loc.); on this see further McKay (1970, pp. 158-159).

31 For the wild olive see Armstrong (2019, pp. $142 \mathrm{ff}$.). "It was fitting that this tree should be kind of olive which grows wild in woodlands: its leaves were smaller than the cultivated olive and the berries unfit for use" (Tilly, 1969, p. 206). With nullo discrimine cf. I, 574 Tros Tyriusque mibi nullo discrimine agetur, where Dido offers to consider Trojans and Tyrians as one -a passage of some relevance to the eventual resolution of the question of how to discriminate between Trojans and Latins. Cf. also X, 108, Tros Rutulusne fuat, nullo discrimine habebo; XII, 498-499 (Aeneas' indiscriminate slaughter). In the reconciliation of Juno, Jupiter will most certainly apply discrimen in his consideration of Troy versus Ausonia.

32 Note here Thomas (1988, pp. 261-273).

33 Cf. the close of Horace's Pyrrha ode, c. 1.5.13-16. For the seemingly inappropriate association of the woodland god with shipwreck survival see Tarrant (2012, p. 285).

34 Is it possible that part of Virgil's point in this passage is that Venus -who will soon enough intercede to secure Aeneas' spear from the Faunian trunk- is less than pleased at the usurpation of her function as a marine goddess and savior of those castaway at sea? The locus of Aeneas' successful evasion of the storm in Book I was a Nympharum domus (I, 168); there were no thanksgiving rites celebrated by the Trojans on landing in Libya.

35 For the synecdoche of stirps for truncus at XII, 770 see Traina, 2017 (reprint of the 2004 second edition), p. 170. There is a deliberate contrast between the action of the impious Aeneas (who fixes a spear in the tree, even if inadvertently), and the Laurentians who had been accustomed to fix offerings there (XII, 768 ... figere dona solebant).

36 There is an element of recollection here of the headless trunk of Faunus' son Tarquitus at X, 555. On the characters in the epic who become trunci (Priam; Rhamnes; Tarquitus; Mezentius), see Dyson (2001, p. 176). The obvious enough parallels between Aeneas' attempted retrieval of his spear and the problem of the Golden Bough are not directly relevant to our study.

37 Cf. VIII, 146 of the gens Daunia with whom Aeneas will do battle.

38 With indignata cf. VII, 770 (Jupiter indignant at the resurrection of Hippolytus); VIII, 728 (of the personified Araxes); and, most importantly, XII, 831 and XII, 952 of the respective shades of Camilla and Turnus.

39 For a helpful start to explicating this key passage, note Binder (2019, pp. $649 \mathrm{ff}$.), with up to date bibliography.

40 Trojan pietas is called into question on two occasions, we might note, associated with Faunus: first there was Aeneas' slaying of the god's son Tarquitus, and then the cutting down of the sacred tree on the battlefield.

41 For the verb cf. XII, 492, of Aeneas as he ducks down on his knee when facing Messapus, whose spear shears off the plumes from the Trojan's helmet. Elsewhere the verb is used in the poem of the settling down of Acestes' lot in the arrow competition at V, 498; of the pacification of the waves at V, 820; and of Aegisthus waiting for Agamemnon (XI, 268).

42 De Rerum Natura IV, 580 ff. Cf. Ennius, Annales fr. 206-207 Skutsch scripsere alii rem / Vorsibus quos olim Faunei vatesque canebunt (with the editor's commentary notes, The Annals of Q. Ennius, Oxford, 1985, p. 372; also de Melo (2019, pp. 442-443; 942).

43 De Rerum Natura IV, 589 fistula silvestrem ne cesset fundere musam. For Pan as a god of music cf. Virgil, Eclogue II, 31-33 mecum una in silvis imitabere Pana canendo: / Pan primus calamos cera coniungere pluris / instituit ...; also Eclogues IV, 58-59 and VIII, 24. Pan is one of the deities who came to console Gallus; so too Apollo and Silvanus (Eclogue X, $21 \mathrm{ff}$.).

44 On the Virgilian Pan note especially Cosi in F. Della Corte (1988, pp. 948-950); also Bailey (1935, pp. 144-147). For how Pan is dismissed by Lucretius, only to be mentioned by Virgil in connection with the future site of Rome, see Hardie (1986, pp. 218-219). "Hierher gehört auch die ganze Beschreibung des frühen Kapitolhügels und seiner Naturmystik ...” (Wimmel, 1973, p. 58).

45 O’Hara, 2017, p. 210 notes that Evander can make reference only to pre-Romulean myths; he compares VIII, 630-631, where the cave of the Lupercal is referenced in connection to the she-wolf.

46 The adjective Lycaeus appears only here in Virgil's epic; cf. Georgic I, 16 as well as Eclogue II, 33 ... Pan curat ovis oviumque magistros.

47 Servius already recognized this (lupus + arcere); cf. ovium custos of Pan at Georgic I, 17. O'Hara, 2017, p. 209, notes that Virgil does not seem to make explicit allusion to this association in the brief etymological comment of Evander.

48 For "Parrhasian" cf. XI, 31, where the same appellation is applied to Evander himself.

49 Cf. Ovid, Fasti II, 421-424; Eden (1975, p. 111). The proem to the first georgic observes something of the same distinction made by Evander: plural "fauns" are invoked, as well as Pan; Pan is favens, but there is no separate mention 
of Faunus -the two gods have been neatly conflated, with favens securing the clear evocation of the native Italian god (cf. Georgic II, 494, where Pan is mentioned alongside the rustic god Silvanus and the nymphs). The association of Pan and Faunus is also Horatian (cf. c. I, 17); it is impossible to know for certain whether Horace or some other author first introduced the (natural enough) conflation.

50 ipse nemus linquens patrium saltusque Lycaei / Pan, ovium custos, tua si tibi Maenala curae, / adsis, o Tegeaee, favens ... (Georgic I, 17-18). All quotes from the Eclogues and Georgics are taken from Ottaviano and Conte, 2013.

51 Mention must also be made of the very obscure myth referenced by Virgil at Georgic III, 391-393 (munere sic niveo lanae, si credere dignum est, / Pan deus Arcadiae captam te, Luna, fefellit / in nemora altra vocans; nec tu aspernata vocantem), where Pan is said to have seduced the goddess Luna with the lure of a snow-white fleece. Even Virgil questioned the veracity of the legend (si credere dignum est); for the scanty extant sources and commentary note Richter (1957, p. 309). See further here Fratantuono (2019, pp. 61-79). Vocans/vocantem alludes to the god's musical talents; the trickery (fefellit) is befitting a son of Mercury. Elaine Fantham notes that Pan is relatively neglected in the Aeneid because "his associations and register are generically inappropriate" (VE II, p. 963). The Gerogics allows for lore of a more randy nature. Similarly, there is no hint in Virgil of the sort of thing one finds at Ovid, Fasti II, 303-358 (Faunus and Omphale). The Pan-Luna story is the sole reference to the more scandalous aspects of the rustic god's résumé -and even here, the poet's si credere dignum est casts a veil over the smut.

52 For the god note Trisoglio in Della Corte (1988, pp. 853-854); also Nisbet and Rudd (2004, p. 354).

53 Aeneid VIII, $600 \mathrm{ff}$.

54 Bailey, 1935, p. 30.

55 For Virgil "Pelasgian” would seem to mean little more than "Greek"; cf. Herodotus I, 58, where they were a distinct people with their own language before merger with the Greeks. Just which Greeks are meant here was a matter of dispute even in antiquity. What we find here is an exact parallel to the case of Pallanteum with its Arcadian presence. Fordyce ad VIII, 600 notes that "the prehistoric inhabitants of Caere could not have been worshipping a god with the Latin name of Silvanus, a spirit of the wild woodland who later became a deity of the farmer." But this is precisely Virgil's point: the rustic deities like Silvanus and the fauns have always been on site, and the local denizens -whether Pelasgians or Arcadians- have always acknowledged their numinous presence. There is a neat balance in Virgil's presentation, with VIII, 600 ... sacrasse Pelasgos followed two verses later by 602 ... habuere Latinos.

56 Note also the egelidum flumen of VIII, 610.

57 I, 20, et teneram ab radice ferens, Silvane, cupressum. The cypress is also connected to Diana (Aeneid III, 680).

58 Georgic II, 493-494, fortunatus et ille deos qui novit agrestis, / Panaque Silvanumque senem Nymphasque sorores. This is the stuff of the idyllic fantasy; there may also be a nod to Lucretius.

59 Eclogue X, 24-25, venit et agrestis capitis Silvanus honore, / florentis ferulas et grandia lilia quassans.

60 For the connection between Latinus' Circean fire-breathing horses and the chimaera-crest of Turnus at VII, 786, see Putnam (1970, pp. 408-430).

61 The language of 280, geminosque iugalis, underscores the marital connection of the offering.

62 The adjective nothus occurs elsewhere in Virgil only at IX, 697 (of one of Turnus' victims).

63 Cf. Aeneid VIII, 314 and XII, 823. 